Monica Reichenberg

Universitet i Gøteborg

Britt-Marie Emanuelsson

Läs- och skrivstudion, Partille kommun

\title{
Elever i årskurs 3 läser och samtalar om texter: En interventionsstudie
}

\section{Sammanfattning}

Svenska elevers läsförståelse har försämrats avsevärt. I PISA 2012 hamnade Sverige under OECD genomsnittet. Samtidigt visar studier att elevers läsförståelse kan öka om de får strukturerad undervisning. I denna interventionsstudie deltar 71 elever från årskurs 3. Syftet med studien var att utvärdera två metoder för läsförståelse, Reciprocal Teaching (RT) och Questioning the Author (QtA). Eleverna fick träna fyra gånger per vecka under åtta veckor. Sammanlagt blev det 32 samtal. Hälften av eleverna fick träna efter Reciprocal Teaching (RT), medan den andra hälften fick träna efter Questioning the Author (QtA). Alla elever deltog i alla 32 samtalen där de fick läsa berättande texter. Eleverna testades före och efter interventionen. Resultaten visade på en signifikant ökning i läsförståelse vare sig eleverna hade tränat efter RT eller QtA. Även elevernas läshastighet av sammanhängande text ökade i båda betingelserna, men den ökade mest för de elever som fått träna efter QtA.

Key words: strategiinriktad undervisningsmetodik, innehållsinriktad undervisningsmetodik, läsförståelse, intervention

\section{Inledning}

PISA 2012 var nedslående läsning för svenskarna. Det visade sig att svenska 15åringars läsförståelse ytterligare hade försämrats. För första gången presterade svenska elever under OECD-genomsnittet (Skolverket, 2013). Från att 2000 ha tillhört toppnationerna i läsförståelse finns det nu endast tre OECD-länder som har lägre resultat.

Forskare, politiker och gemene man ställde sig frågan: Hur hade detta kunnat ske i Sverige som ju hade rykte om sig att vara en välfärdsstat där stora summor satsats på skolväsendet under årens lopp (Antikainen, 2006). Det finns givetvis många förklaringar till tillbakagången. En som ofta nämnts är det skifte som skett inom svenskt undervisningsväsende. Från att ha haft fokus på gemensamma genomgångar i helklass har det blivit alltmer fokus på "tyst eget 
arbete”. Det har inneburit att den enskilde läraren mer eller mindre har tvingats abdikera från sin lärarroll och istället fått bli handledare (Carlgren et al., 2006). Denna förändrade lärarroll har avspeglat sig i läsundervisningen. Här har ostrukturerad upplevelseläsning av bänkböcker och "recensionsskrivande" på egen hand dominerat på bekostnad av explicit undervisning i läsförståelse (Ewald 2007; Asklund, 2008; Knutas, 2008). En annan bidragande faktor till den svenska nedgången som återkommande lyfts fram är att på vissa lärarutbildningar har kurserna i läs- och skrivutveckling varit obligatoriska, på andra har de endast varit valbara. Det fick till följd att det examinerades lärare som skulle undervisa elever i den första viktiga läs- och skrivinlärningen - men som inte hade någon utbildning i hur det ska gå till.

2011 kom en ny lärarutbildning. En av ledamöterna i expertkommittén för den nya lärarutbildningen var framlidne professor Ingvar Lundberg. I den nya lärarutbildningen betonas att tyngdpunkten i grundlärarnas ämnesutbildning ska ligga på grundläggande läs-, skriv- och matematikinlärning. Ett antal av de elever som deltog i PISA 2012 har sannolikt undervisats av lärare som inte haft tillräcklig kompetens inom läs-och skrivområdet.

Efter att PISA offentliggjorts restes krav på att något radikalt måste göras. Ett exempel på en konkret åtgärd är att regeringen nu satsat 800 miljoner och gett Skolverket i uppdrag att utarbeta ett Läslyft för lärare. Läslyftet syftar till att ge lärare kunskap om vetenskapligt väl underbyggda metoder och beprövade arbetssätt för att bättre kunna stödja elevernas läs- och skrivutveckling och individanpassa undervisningen. Läslyftet vänder sig inte bara till lärare som undervisar i svenska utan också till lärare som undervisar i samhällsorienterande - och naturorienterande ämnen.

Här blir det intressant att se vad för vetenskapligt underbyggda metoder och beprövade arbetssätt som avses. Under de senaste åren har det varit mycket fokus på en metod, Reciprocal Teaching (RT) (Palincsar \& Brown, 1984) i svenska populärvetenskapliga publikationer (Westlund, 2009) och i projektet "En läsande klass". Detta projekt har initierats av Martin Widmark, som är Sveriges mest läste barnboksförfattare. Projektet har fått stort genomslag då en bok, som innehåller en studiehandledning och texter, har skickats ut gratis till varje låg- och mellanstadium i Sverige under våren 2014.

Det torde vara svårt att finna en metod som är så väl beforskad som RT (se områdesöversikt i nästa avsnitt). Vårt argument i denna artikel är att strukturerade metoder för undervisning i läsförståelse är viktiga för att utveckla elevers läsförståelse men det är också viktigt att inte bara förlita sig på en metod hur väl beforskad den än visat sig vara. Elever är olika och lärare är olika. Vad som är bra för en behöver inte vara bra för den andra. RT har inte tidigare använts i större studier i svensk grundskola. Däremot har den prövats i en interventionsstudie i särskolan (Lundberg \& Reichenberg, 2013). En annan metod, Questioning the Author (QtA) (Beck \& McKeown, 2006) har däremot används i studier i grundskolan (se t. ex Reichenberg, 2008). 
Mot bakgrund av ovanstående är syftet med denna interventionsstudie att utvärdera Reciprocal Teaching och Questioning the Author med elever i årskurs 3.

\section{Områdesöversikt}

\section{Strategiorienterad undervisning}

Forskningen om undervisning i läsförståelse har främst intresserat sig för strategiinriktad undervisningsmetodik och innehållsinriktad undervisningsmetodik (McKeown, Beck \& Blake, 2009a,b).

Exempel på den förra är: Reciprocal Teaching (RT) (reciprok undervisning) (Palincsar \& Brown, 1984), Transactional strategies (transaktionell strategiundervisning) (Pressley et al., 1992), Concept-oriented learning instruction (begreppsorienterad undervisning), (Guthrie et al., 1996). Se också National Reading Panel (2000) där ytterligare studier finns omnämnda. Den tveklöst mest utforskade av de tre är RT och den kommer därför att behandlas mer utförligt här medan övriga får en något mer kortfattad beskrivning.

I transaktionell strategiundervisning får eleven träna hur man föregriper innehållet i texten, aktiverar förkunskaper när man läser texten, genererar frågor om innehållet i texten, sammanfattar, konstruerar bilder som representerar idéer i texten och anpassar läshastigheten till sin egen förståelse. Lärarens roll är att förklara och modellera. I början är läraren mycket aktiv för att sedan mer och mer lämna över till eleverna (Pressley et al., 1992. Se också Andreassen, 2008, s. 58f.; Pressley \& Wharton-McDonald, 2002).

I begreppsorienterad undervisning får eleven träna hur man aktiverar förkunskaper, genererar frågor om innehållet i det lästa, söker information, dvs. hur man kombinerar ny information med information som man mött tidigare i texten, sammanfattar och gör en grafisk organisation av texten. Det senare innebär att eleverna ska konstruera en visuell eller spatial representation utifrån det lästa. Det kan röra sig om en teckning, en begreppskarta eller ett diagram. Lärarens roll är också här att förklara och modellera. I början är läraren mycket aktiv för att sedan mer och mer lämna över till eleverna.

I RT (Palincsar \& Brown, 1984) tränas fyra strategier:

1. Förutspå/förutsäga/ställa hypoteser om handlingen. Med hjälp av t ex rubrik och bilder ska eleverna öva på att förutspå vad de tror att texten kommer att handla om, dvs. göra inferenser. Det innebär också att eleverna ska kunna dra slutsatser från vad de redan vet i ljuset av ny information som dyker upp i texten.

2. Ställa egna frågor före, under och efter läsningen av texten. Eleverna ska öva sig i vad som är viktigt, att skilja det väsentliga i texten från det oväsentliga. 
3. Reda ut oklarheter, exempelvis svåra ord, komplicerad syntax, centrala idéer.

4. Sammanfatta texten med egna ord.

Centralt i RT är "guided practice", dvs. lärarstyrda övningar, där läraren tänker högt, modellerar, för att visa eleverna hur strategierna fungerar. Läraren demonstrerar hur man förutspår, ställer frågor, reder ut svåra ställen i texten och sammanfattar det lästa. Eleverna observerar och uträttar i denna fas inte så mycket kognitivt arbete själva. Denna modellering är viktig då de flesta elever sällan har fått reda på hur man tänker för att förstå det man läser. Allteftersom blir det en elevs uppgift att axla lärarens roll som samtalsledare. Läraren blir då en bland övriga deltagare i gruppen, men har samtidigt till uppgift att stödja den elev som är samtalsledare. I en sammanställning från 1994 har Rosenshine och Meister (1994) gått igenom sexton kvantitativa studier som tillämpat RT. Alla visade samma resultat. Efter Rosenshine och Meisters forskningsöversikt har fler studier där RT tillämpats sett dagens ljus som också visar på positiva effekter. Här ska nämnas några: Klingner och Vaughn (1996); Alfassi (1998); Lederer (2000); Hacker och Tenent (2002); Takala (2006); van den Bos et al. (2007); Andreassen (2008); Alfassi et al. (2009); Spörer, Brunstein och Kieschke (2009); samt Lundberg och Reichenberg (2013).

Andreassen (2008) utvecklade en intervention med bakgrund i RT, begreppsorienterad undervisning och transaktionell undervisning. Innan interventionen startade träffade Andreassen lärarna vid fem tillfällen. Under själva interventionsperioden träffade han lärarna vid två tillfällen. I Andreassens studie ingick också en kontrollgrupp som fick sin vanliga läs- och ämnesundervisning.

För att värdera effekten av interventionen bedömde Andreassen elevernas läsförståelse, strategibruk och läsmotivation före och efter undervisningen. Här fann han dock inte någon större effekt av interventionen. Vad elevernas strategibruk beträffar blev det en moderat effekt av den explicita strategiundervisningen. Det blev inte någon effekt av interventionen på elevernas läsförståelse och motivation. Eleverna i experimentgrupperna fick dock långt mer explicit strategiundervisning och var deltagare $\mathrm{i}$ fler lärandedialoger av hög kvalitet än eleverna $\mathrm{i}$ kontrollgruppen. I en uppföljningsstudie har Andreassen och Bråten (2011) gjort ytterligare analyser med hjälp av MANCOVA. Tre av lästesten fungerade som beroende variabler. Här fann Andreassen och Bråten en effekt på läsförståelsen hos de elever som hade fått explicit undervisning i läsförståelsestrategier.

Lundberg och Reichenberg (2013) jämförde RT och Inferensträning (Franzén, 2002). I inferensträning ska eleverna leta efter det rätta svaret. Bara en typ av svar går att finna "precis där " i texten. Vissa svar finns inte ens tydligt utskrivna i texten utan eleverna måste hitta svaret "i sitt eget huvud” med hjälp av ledtrådar i texten. Ytterligare en typ av svar kräver information från mer än 
bara en mening eller ett avsnitt i texten. ${ }^{1}$ Elevernas läsförståelse ökade efter interventionen oavsett efter vilken metod de fått träna efter.

Genomgången av transaktionell strategiundervisning, begreppsundervisning, reciprok undervisning och inferensträning har gett vid handen att de har flera gemensamma drag. I samtliga har läraren rollen som den som synliggör strategierna för eleverna. Det sker genom att läraren tänker högt och modellerar. I samtliga återkommer också strategierna föregripa, sammanfatta och generera frågor. Däremot förekommer endast reda ut oklarheter i RT.

\section{Innehållsorienterad undervisning}

Ser vi till innehållsorienterad undervisningsmetodik finns det betydligt färre studier. Här ska nämnas Instructional conversations (Goldenberg, 1992; Saunders \& Goldenberg, 1999; McIntyre, Kyle \& Moore, 2006) och Questioning the Author. Den mest kända torde dock Questioning the Author vara. Här har Beck och McKeown (2006) gjort ett antal studier. I Sverige har metoden använts av Reichenberg (2008). I denna studie ingick också en kontrollgrupp.

Avsikten med innehållsorienterad undervisningsmetodik är att eleverna ska skapa mening i texten samtidigt som de läser. Lärarens uppgift är här liksom i RT att leda eleverna genom textinnehållet.

Questioning the Author går, som namnet antyder, ut på att ifrågasätta textförfattaren. Metoden kan användas för såväl faktatexter som skönlitterära sådana.

Avsikten med ifrågasättandet är att uppmärksamma läsaren på att det bakom varje text döljer sig en författare. Denne författare glömmer ibland vilken målgrupp han/hon skriver för. Det kan föra med sig att författaren hoppar över för förståelsen viktiga tankeled. Det händer också att författaren uttrycker sig oklart, inkonsekvent eller använder en alltför komplicerad vokabulär respektive syntax. Inte heller talar författaren till läsaren eller ställer frågor till denne. Avståndet mellan texten och läsaren blir därför stort. Det kan leda till att läsaren, i det här fallet eleven, inte känner sig manad att vara aktiv och medskapande under läsningens gång.

QtA vill bryta ner avståndet mellan läsare och författare. Den vill uppmärksamma eleverna på att författaren har ett stort ansvar när det gäller texters läsbarhet och att eleverna har all rätt att ifrågasätta författarens auktoritet. QtA vill således lyfta skuldbördan från eleverna till författaren, dvs. få dem att inse att det är den senare som kan uttrycka sig oklart och inkonsekvent. Men, QtA nöjer sig inte med att få eleverna att kritisera utan syftar också till att träna dem

\footnotetext{
${ }^{1}$ Inspiration till modellen fick Franzén i en artikel av Raphael (1982) i Reading Research Quarterly.
} 
på att bli aktiva, medskapande läsare genom att få dem att ställa egna frågor till texten och komma med förslag till omformuleringar av den.

För att framgångsrikt kunna ställa frågor till texten måste läraren skola in eleverna i den aktiva läsarrollen. Det sker genom att eleverna, under lärarens ledning, läser en text som läraren delat upp (segmenterat) i kortare avsnitt. Uppdelningen har skett dels där läraren har förutsett att eleverna skulle få problem med att förstå, dels där läraren vill uppmärksamma en central tanke i texten. Läsningen avbryts då av frågor och reflektioner som följs av diskussioner. För att inte helheten ska gå förlorad, sammanfattar läraren vad som lästs i det aktuella avsnittet och knyter samman det med vad som lästs i de tidigare textavsnitten innan man går vidare. Detta är något helt annat än att först läsa hela texten och sedan samtala om innehållet.

Beck och hennes kollegor har utarbetat två olika slag av frågor (queries) att användas under den gemensamma textläsningen: ingångs- och uppföljningsfrågor. Avsikten med dessa frågor är att stödja elevernas förståelse av vad de läser och inte fokusera hela intresset på vad de just har läst. Det senare kan ofta vara fallet när frågorna till en text kommer först när hela texten är läst (Beck \& McKeown, 2006).

Ingångsfrågorna är tänkta att vara just ”ingångar” till texten för att få fram författarens övergripande budskap och idéer. Frågorna ska uppmärksamma textens viktigaste delar, och påminna eleverna om att det bakom de skrivna tankarna återfinns en författare som står för dessa åsikter. Kännetecknande för frågorna är att textförfattaren tas in i sammanhanget. På samma gång ska frågorna lägga ansvaret på eleverna att själva söka förstå texten och tänka sig in i problemställningarna. Exempel på “ingångsfrågor” är: Vad är det författaren vill säga? Vilket budskap vill författaren framföra?

Sedan eleverna fătt denna "ingång” i texten, ställer läraren så kallade "uppföljningsfrågor". Dessa har ett delvis annat syfte och de fokuserar på viktiga delar av innehållet. Avsikten är att få eleverna att gå under textytan och försöka få fram vad texten egentligen betyder och på vilket sätt eleverna uppfattat innebörden i det aktuella textavsnittet. En annan avsikt är att få eleverna att fundera över hur det de läst hänger ihop med vad de läst tidigare i texten och med sina förkunskaper om textens ämne.

Exempel på uppföljningsfrågor är: Vad menar författaren med det? Hur hänger det ihop med vad författaren skriver här mot vad vi tidigare fått veta? Vad har författaren lagt till här för att det ska framgå tydligare vad han/hon menar? Alternativt: Har författaren uttryckt sig tillräckligt klart? Hur skulle ni ha uttryckt er? Vad saknas i texten? Vad måste vi själva lägga till för att förstå?

Uppföljningsfrågorna är också tänkta som hjälp för eleverna att ta reda på varför de misstolkat en text: Fick vi veta det av författaren? Gav författaren oss ett svar på det? Genom att textförfattaren dras in får eleverna möjlighet att träna källkritik. Med tanke på att skolelever kommer i kontakt med en stor mängd information och läser många webbtexter är det viktigt att de får en vana i att 
ifrågasätta vad de möter (Beck \& McKeown, 2006, jfr Ferguson, Bråten, Strømsø \& Anmarkrud, 2013).

För att hjälpa eleverna att ta ansvar för sitt tänkande kan läraren använda nedanstående strategier/discussion moves:

Marking. Används när läraren vill fästa elevernas uppmärksamhet på något viktigt i texten. Eleverna inbjuds då att komma med inlägg. Sedan kan läraren be övriga deltagare att ta ställning till vad en elev sagt.

Turning back. Brukas om eleverna försöker "bolla över” ansvaret för tänkandet. Då är det lärarens uppgift att återge eleverna ansvaret (turning back). Avsikten är att eleverna genom att lyssna till sina kamraters inlägg skall komma fram till en djupare förståelse än vad de hade tidigare.

Annotating. Ibland behöver eleverna hjälp eftersom det kanske saknas alltför många tankeled i texten, då kan läraren behöva fylla i underförstådd information för att läsningen skall kunna gå vidare.

Modelling. Läraren fungerar som modell för inlärning genom att tänka högt, gå framåt och bakåt i texten, läsa högt, reflektera över det lästa och diskutera det med eleverna.

Revoicing. Om eleven har svårt att formulera sig, då kan läraren tolka det de försöker uttrycka.

Recapping. Sammanfatta. Det kan röra sig om att sammanfatta en del av textinnehållet men också hela texten. Det är inte endast läraren utan också eleverna som ska göra detta.

\section{Sammanfattande kommentar}

Ovanstående genomgång har uppmärksammat att RT och QtA har flera likheter: (a) hela texten läses inte direkt utan läsningen sker online, dvs. stycke för stycke. Läraren har segmenterat (delat upp) texten i förväg. (b) I början dominerar läraren mycket men efterhand som elevernas metakognitiva färdighet ökar blir de mer självständiga och deras känsla av att kunna bemästra strategierna ökar (jfr Bandura, 1986). (c) RT och QtA har sina rötter i utvecklingspsykologi (Massey, 2009) och (d) metoderna har använts i klassrum av lärare och då har det gemensamma samtalet varit centralt. Den bärande tanken är alltså att samtalet skall fungera som stöd "scaffolding" för att utveckla elevernas metakognitiva färdigheter. Stödet i samtalet kommer dels från läraren dels från kamraterna. Genom att ställa frågor och bolla idéer mot lärare och kamrater lär sig eleven att utveckla sina egna metakognitiva färdigheter. Här finns en tydlig teoretisk koppling till Vygotskys (1978) teori om att eleven kan använda samtalet som ett "verktyg” för att strukturera sitt tänkande. Det finns också en tydlig koppling till Bruners teori om scaffolding, vilket är en precisering av Vygotskys teori (Wood, Bruner \& Ross, 1976). Såväl RT som QtA betonar båda vikten av elevens eget lärande. Följaktligen finns det också en koppling till Banduras teorier om självreglerat lärande (1986). 
En skillnad mellan RT och QtA är dock att i den senare är det större fokus på själva textprocessandet. I samtalet inbjuds eleverna till att gemensamt och strukturerat "consider meaning, to develop and grapple with text ideas" (Kucan \& Beck, 1997, s. 290) för att därigenom skapa mening i vad de läser.

Tidigare nordiska studier har inte jämfört RT och QtA. Däremot finns en amerikansk studie McKeown, Beck and Blake (2009a, b) som jämfört strategiinriktad undervisningsmetodik med innehållsinriktad undervisningsmetodik. I den strategiinriktade metodiken fick eleverna direkt undervisning om speciella strategiska procedurer, såsom hur man sammanfattar ett textsegment, hur man gör inferenser och ställer frågor på texten. Sedan fick eleverna öva på hur man använder sådana strategier när man läser en text. I den innehållsinriktade metodiken handlade det om hur man skulle inrikta och upprätthålla elevernas uppmärksamhet på innehållet i det man läste, hur man byggde upp inre mentala representationer av de tankar och idéer som finns i texten och hur man knöt ihop dessa (jfr Kintsch, 1998). Undersökningen pågick i två år. Resultatet blev entydigt. Den innehållsorienterade metodiken gav det klart bästa resultatet både när det gäller att förstå berättelser och faktatexter.

\section{Metod}

\section{Urval}

I studien deltog 71 elever från fyra klasser i årskurs 3 som rekryterades från två skolor i västra Sverige. Det var 39 pojkar och 32 flickor och deras genomsnittliga ålder var 9,01 år. Alla elever hade i slutet av årskurs 1 deltagit i en (kommunövergripande) screening. I denna ingick ordavkodning av ord och non-ord, högläsning med återberättande, läsförståelse vid tystläsning med och utan bildstöd, hörförståelse samt diktamen på ljudenligt stavade ord. De elever som inte nådde önskvärda resultat fick anpassad träning under höstterminen i årskurs 2.

Fyra lärare, samtliga kvinnor, mellan 42 och 59 år deltog i studien. Deras undervisningserfarenhet varierade mellan 15 och 38 år. Samtliga lärare hade således en mångårig erfarenhet av att undervisa.

Deltagandet byggde på frivillighet. Det är idag förenat med visa svårigheter att rekrytera lärare i Sverige till interventionsstudier. Dylika studier sträcker sig över en längre period och lärarna måste sätta sig in i en speciell metod som forskarna tränar dem i på seminarier. Många lärare tycker följaktligen att detta tar för mycket tid i anspråk och tackar därför nej med motiveringen tidsbrist.

Vad gäller urval av metoder valdes RT av två skäl: (a) metoden har fått ett stort genomslag i populärlitteraturen (b) den har i tidigare svenska studier endast använts i särskolan där elever med utvecklingsstörning går (Lundberg \& Reichenberg, 2013). Vad gäller val av QtA betingades det av att Reichenberg inte prövat metoden med elever i årskurs 3 i tidigare studier. 


\section{Etik}

Elevernas föräldrar fick fylla i en samtyckesblankett där det stod att deltagandet i studien var frivilligt och att man när som helst kunde avbryta sin medverkan. Även eleverna fick detta förklarat för sig muntligt.

\section{Genomförande}

Interventionen försiggick $\mathrm{i}$ tre steg. Steg 1. Här testades elevernas avkodningsförmåga och läsförståelse. För att testa avkodningen användes testet Ord - och bokstavskedjor. Det består av två deltest. Det första, ordkedjetestet, testar avkodningsförmåga på ordnivån och går ut på att eleven markerar med ett streck var mellanrummen ska vara i en sekvens av tre sammanskrivna ord t ex orden snöbåtko, gulgrynute, brordåligbulle. Här skall då eleven markera på följande sätt: snö|båt|ko, gul|gryn|ute, bror|dålig|bulle.

En tidsgräns på två minuter sattes och resultatet blev alltså hur många korrekta markeringar eleven hann med på denna tid. Testet har flitigt använts i svenska skolor och ger ett snabbt och säkert besked om hur väl eleven förmår att identifiera (avkoda) skrivna ord ( Lundberg \& Reichenberg, 2013).

Det andra deltestet, bokstavskedjetestet, går ut på att eleverna skall identifiera bokstäver och markera med ett streck mittemellan par av lika bokstäver, t ex KSBBSOOFE, ÅFFKJNNÅES. Här skall då eleven markera på följande sätt: KSB|BSO|OFE, ÅF|FKJN|NÅES. Sammanlagt ingår 60 bokstavskedjor. På 2 minuter skall eleven markera så många som möjligt. Testuppgiften i bokstavskedjor liknar uppgiften $\mathrm{i}$ ordkedjor med det undantaget att bokstavssekvenserna inte ska läsas. Syftet med bokstavskedjor är att få en uppfattning om visuo-motorisk snabbhet (Jacobson, 2001).

På ordkedjetestet kan man få 60 poäng och på bokstavskedjetestet 60 poäng. En fördel med bokstavs- och ordkedjetestet är att det tidigare har använts i ett stort läsprojekt Läsutveckling i Kronoberg. 2

För att testa läsförståelsen på meningsnivån användes Vilken bild är rätt? (Lundberg, 2001). Eleven får se en serie om fyra nästan likadana bilder. Under bildserien finns en eller flera meningar, t ex Max sparkade sin randiga boll. I en bild ser man en pojke som sparkar en svart boll, i nästa kastar han en randig boll, i den tredje bilden står han med en boll under armen, och i den fjärde bilden sparkar han en randig boll. Den fjärde bilden ska alltså markeras med ett streck. Sammanlagt ingår 38 sådana bildserier med tillhörande skrivna meningar. Tidsgränsen är 10 minuter. Ett bra resultat på denna uppgift kräver av eleven visst flyt i läsningen, precision i ordavkodningen samt förståelse av meningens innebörd. Det handlar alltså inte om förståelse på någon högre nivå, men är ändå

\footnotetext{
${ }^{2}$ Läsutveckling i Kronoberg är ett tvärvetenskapligt, longitudinellt forskningsprojekt som påbörjades 1986. Syftet var att på grundval av de senare årens framsteg inom dyslexiforskningen utveckla och utvärdera praktiskt användbara metoder, instrument och hjälpmedel för effektivare diagnos och behandling av elever med lässvårigheter (Jacobson, 1995, s 41).
} 
fråga om grundläggande förutsättningar för sådan förståelse. På detta test kan man få sammanlagt 38 poäng.

Eleverna i vår studie fick byta penna efter 5 minuter och sedan fortsätta övningen. Eleverna fick också läsa en löpande text. Vi valde Igelkotten 3(Madison, 1998). Texten skildrar igelkotten och dess levnadsvanor. Det är, som nämnts, en löpande text, där eleverna med jämna mellanrum skall visa att han/hon förstått genom att välja rätt ord av tre s.k. lucktest. Eleven håller på tills uppgiften är klar (401 ord) och man räknar ut antal rätt och läshastighet för varje elev. På detta test kan man få sammanlagt 13 poäng. Samtliga test genomfördes på gruppnivå av andraförfattaren till denna artikel. Testningen skedde i september 2013.

Steg 2. Efter testningen följde själva läsinterventionen under oktober december 2013. Under åtta veckor fyra gånger per vecka fick eleverna ha textsamtal i grupp. Sammanlagt blev det således 32 textsamtal. Hälften av eleverna tränade efter RT och hälften tränade efter QtA. Varje textsamtal varade i cirka 30 minuter. Alla elever deltog i samtliga textsamtal. Om elever var sjuka eller frånvarande fick de ta igen detta sedan. I tidigare studier av Reichenberg (2008) har det endast ingått sex elever i varje grupp. I denna studie däremot har det varit upp till elva elever i varje grupp. De texter som användes var berättande (narratives). Vid varje textsamtal läste såväl lärare som elever texten högt. Definitionen av en berättande text är enligt Pappas (1991):

The critical feature of narrative texts include "make - believe" elements, a story structure (plot), characterization, and conflict. Texterna hämtades ur Eve Malmqvists och Bertil Forsbergs Vad var det jag läste? och Harriet Söderbloms Sagor att läsa och berätta. Eleverna hade enligt lärarna inte varit i kontakt med texterna tidigare.

Innan vi startade fick alla deltagande lärare och rektorerna på deras skolor en gemensam föreläsning om läsning och läsförståelse som hölls av förstaförfattaren till denna artikel. Sedan träffade vi de fyra lärarna på seminarier före och under interventionen. Eftersom två av lärarna använde RT och två av lärarna använde QtA kunde vi inte träffa dem på gemensamma seminarier. Om vi gjort så hade risken varit överhängande att lärarna hade blandat metoderna i sin undervisning. För att inte få problem med validiteten träffade vi lärarna två och två åt gången. Alla fyra lärarna fick lika många seminarier - fem - och vi var båda närvarande. På seminarierna gick vi igenom forskning kring läsförståelse. Tid ägnades också åt att analysera och segmentera texter. Vid textanalysen tog vi upp vad som kan göra en text svår att förstå för elever i årskurs 3. Vidare gick vi igenom respektive metod noga och hade demonstrationslektioner där förstaförfattaren agerade lärare och lärarna fick vara elever. Centralt i dessa "lektioner” var i RT genomgång av de fyra strategierna,

\footnotetext{
${ }^{3}$ Pinnsvin på norska.
} 
modellering och segmentering. I QtA tog vi, förutom segmentering, också upp hur man kan tillämpa ingångsfrågor och uppföljningsfrågor samt de strategier/discussion moves som är centrala. Lärarna fick också forskningsartiklar om den respektive metod de använde samt boken "Vad är lättläst?” (Lundberg \& Reichenberg, 2009). För att säkerställa metodernas validitet, dvs. att lärarna verkligen använde respektive metod såsom var avsikten besökte en av oss också klassrummen när lärarna hade textsamtal. Efter lektionens slut följde ett samtal med läraren (jfr Andreassen, 2008, s 112).

Steg 3. Då alla elever hade deltagit i 32 textsamtal genomfördes post test i december 2013.

Tabell 1. Deskriptiv statistik för medelvärden, standardavvikelser och korrelationskoefficienter. Bk=bokstavskedjor. $\mathrm{Ok}=$ ordkedjor. $\mathrm{VB}=$ Vilken bild är rätt?

\begin{tabular}{lllllllllllllll}
\hline & M & S.D & 1 & 2 & 3 & 4 & 5 & 6 & 7 & 8 & 9 & 10 & 11 & 12 \\
\hline bk pre & 31,21 & 7,11 & 1,00 & & & & & & & & & & \\
bk post & 35,68 & 7,75 &, 52 & 1,00 & & & & & & & & & \\
ok pre & 16,62 & 7,80 &, 14 &, 12 & 1,00 & & & & & & & & \\
ok post & 21,25 & 7,92 &, 12 &, 22 &, 65 & 1,00 & & & & & & & \\
VB 5 min pre & 13,48 & 4,79 &, 16 &, 18 &, 534 &, 61 & 1,00 & & & & & & \\
VB 5 min post & 17,83 & 5,17 &, 21 &, 29 &, 48 &, 58 &, 77 & 1,00 & & & & & \\
10 min pre & 23,15 & 6,89 &, 16 &, 16 &, 53 &, 57 &, 80 &, 71 & 1,00 & & & & \\
10 min post & 28,76 & 6,55 &, 11 &, 19 &, 49 &, 56 &, 70 &, 79 &, 75 & 1,00 & & & \\
Igelkotten pre & 2,83 & 2,46 &,- 070 &,- 07 &,- 28 &,- 30 &,- 32 &,- 38 &,- 35 &,- 38 & 1,00 & & \\
Igelkotten post & 1,88 & 1,84 &,- 13 &,- 17 &,- 26 &,- 32 &,- 36 &,- 44 &,- 37 &,- 46 &, 45 & 1,00 & \\
hastighet pre & 59,34 & 32,58 &, 12 &, 13 &, 55 &, 54 &, 57 &, 47 &, 59 &, 49 &,- 16 &,- 21 & 1,00 \\
hastighet post & 74,58 & 35,88 &, 11 &, 15 &, 55 &, 56 &, 63 &, 57 &, 62 &, 54 &,- 24 &,- 27 &, 69 & 1,00 \\
\hline
\end{tabular}

Notera; Kendall's tau_b,

\section{Resultat}

\section{Initiala gruppskillnader}

Sammanfattningsvis skiljde sig grupperna signifikant åt på två tester före interventionen. Av Tabell 1 kan man utläsa att det inte fanns några signifikanta skillnader på bokstavskedjor mellan grupperna $t(69)=-1.094, p=$ n.s. Det fanns inte heller några signifikanta skillnader på ordkedjor mellan grupperna $t(69)=$ 1.094, $p=$ n.s. Vidare fanns det inga signifikanta skillnader på Vilken bild är rätt? 5 min. mellan grupperna $t(69)=-1.522, p=n$.s och inte heller fanns det några signifikanta skillnader på Vilken bild är rätt? 10 min. mellan grupperna $t(69)=-.807, p=$ n.s. Det fanns däremot signifikanta skillnader på Igelkotten mellan grupperna $t(64)=-2.702, p=>.05$. Det fanns också signifikanta skillnader på Läshastighet av den sammanhängande texten Igelkotten mellan grupperna $t(68)=-2.909, p=>.05$ 
Sammanfattning av variansanalys. Tabell 2 visar att det fanns åtskilliga huvudeffekter av interventionen(tid), men bara en interaktionseffekt(tid*grupp). Medelvärden (M) och standardmedelfel (S.E.) presenteras i Tabell 2. Effektstorleken var god för Vilken vild är rätt? vid 5 och 10 minuter.

Bokstavskedjor. Huvudeffekten av interventionen på bokstavskedjor var signifikant $F(1)=30.115, \quad p=>.001$. Eta-kvadraten var $\eta=.331$. Interaktionseffekten av tid och gruppen var däremot inte signifikant $F(1)=.421$, $p=$ n.s.. Eta-kvadraten var $\eta=.007$.

Ordkedjor. Huvudeffekten av interventionen på ordkedjor var signifikant $F(1)=66.878, p=>.001$. Eta-kvadraten var $\eta=.523$. Interaktionseffekten av tid och gruppen var däremot inte signifikant $F(1)=.605, p=$ n.s.. Eta-kvadraten var $\eta=.010$.

Vilken bild är rätt? 5 min. Huvudeffekten av interventionen på Vilken bild är rätt? 5 min var signifikant $F(1)=203.816, p=>.001$. Eta-kvadraten var $\eta=.770$. Interaktionseffekten av tid och gruppen var inte signifikant $F(1)=1.821, p=$ n.s. Eta-kvadraten var $\eta=.029$.

Vilken bild är rätt? 10 min. Huvudeffekten av interventionen på Vilken bild är rätt? 10 min. var signifikant $F(1)=162.209, p=>.001$. Eta-kvadraten var $\eta=.727$. Interaktionseffekten av tid och gruppen var däremot inte signifikant $F(1)=.351$, $p=$ n.s.. Eta-kvadraten var $\eta=.006$.

Igelkotten. Huvudeffekten av interventionen på Igelkotten var signifikant $F(1)=14.427, p=>.001$. Eta-kvadraten var $\eta=.191$. Interaktionseffekten av tid och gruppen var inte signifikant $F(1) .048, p=$ n.s.. Eta-kvadraten var $\eta=.001$.

Läshastighet. Huvudeffekten av interventionen på Läshastighet var signifikant $\quad F(1)=64.178, \quad \mathrm{P}=>.001$. Eta-kvadraten var $\eta=.513$. Interaktionseffekten av tid och gruppen var signifikant $F(1)=8.100,=\mathrm{P}=>.05$. Eta-kvadraten var $\eta=.117$.

Kommentar: Resultaten i Tabell 2 är i linje med studiens argument, nämligen att strukturerade interventioner i läsförståelse spelar roll. Effekten av interventionen var signifikant på alla tester. Effektstorleken av interventionen var stark för ordkedjor och Vilken bild är rätt? vid 5 respektive 10 min. Medan effektstorleken för Igelkotten och bokstavskedjor var låg.

Vidare visar Tabell 2, frånvaron av gruppeffekter på alla test utom läshastighet. Resultatet indikerar, i linje med studiens argument, att vilken metod man använder egentligen inte spelar roll statistiskt sett. Den ökade läshastigheten av sammanhängande text - Igelkotten - säger inget om elevernas förståelse av texten. Följaktligen kan man misstänka att ökningen av elevernas läshastighet är en bieffekt av interventionen till följd av upprepad högläsning av texterna. Den typen av effekter är alltid ett hot mot studiens interna validitet (cf. Campbell \& Stanley, 1966, Cook \& Campbell, 1979). Den låga effektstorleken skulle kunna tolkas som ett stöd för denna förklaring. Den alternativa förklaringen av resultaten är att QtA faktiskt fokuserar på att eleverna skall gå 
på djupet med innehållet i texter och därigenom tvingas eleverna att läsa texterna högt flera gånger för att komma åt textinnehållet.

Tabell 2. Variansanalys för upprepade mätningar, medelvärden (M), standardfel (SE)

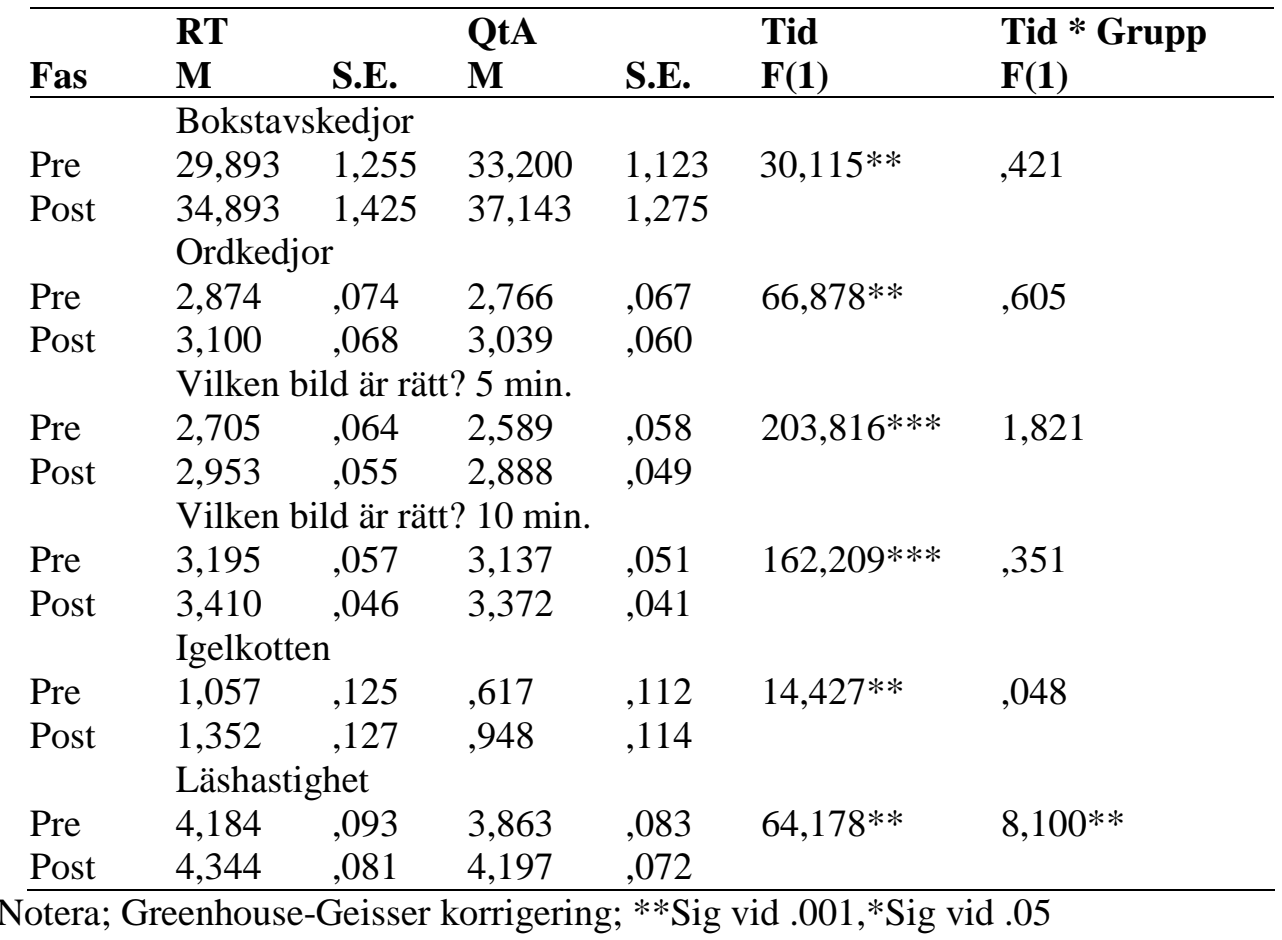

\section{Diskussion}

I denna studie har vi utvärderat två metoder för undervisning i läsförståelse. Den ena bygger på innehållsorienterad undervisningsmetodik medan den andra bygger på en metodik där läraren förklarar och modellerar lässtrategier och tillämpar dem när han/hon leder eleverna genom texten. Tidigare studier där man jämfört innehållsorienterad och strategiinriktad undervisningsmetodik har gjorts i en amerikansk kontext. Vår studie är ett försök att fylla det svenska tomrummet. Resultaten visar att elevernas läsförståelse ökade signifikant oberoende av vilken metod som användes.

Till skillnad från McKeown, Beck och Blakes studie (2009a, b) kunde vi inte få fram några skillnader mellan de två metoderna. Det finns flera förklaringar till detta. McKeown, Beck och Blakes studie pågick i två år medan vår pågick i åtta veckor. I McKeown, Beck och Blakes studie kan man se de långsiktiga effekterna medan vår studie visar på de kortsiktiga. I en åtta veckors intervention kan det vara svårt att få fram skillnader mellan olika undervisningsmetodik. Anledningen till att vi inte lät interventionen pågå i två år som McKeown, Beck och Blake beror av att svenska elever ofta byter lärare i årskurs 4. En annan orsak är det fria skolvalet vilket fått till följd att elever ofta byter skola. En längre pågående interventionsstudie skulle kunna ha ökat risken 
för att studiens interna validitet hade varit i fara, t ex att deltagarna hade kunnat bli uttröttade, flyttat eller bytt skola. Dylika omständigheter kan få till följd att resultaten planar ut och kommer allt närmare medelvärdet (Campbell, 1966). Vidare använde de amerikanska forskarna både berättelser och faktatexter. Kanske hade vårt resultat blivit ett annat om vi också haft faktatexter. Tidigare studier (Reichenberg, 2000, 2013) visar att det är just faktatexter som är svåra för elever och här behövs verkligen att de får gå i närkamp med texten. Anledningen till att eleverna i denna studie inte fick läsa faktatexter är att de när vi började studien var förhållandevis ovana vid det. Det är först i årskurs tre som faktatexter i allt större utsträckning införs i svensk skolundervisning (Lundberg, 2010). Eleverna i McKeown, Beck och Blakes (2009) studie gick i årskurs 5.

Även elevernas läshastighet av enskilda ord - ordkedjor - enskilda meningar -Vilken bild är rätt? - och sammanhängande text - Igelkotten - ökade i båda betingelserna, men läshastigheten av sammanhängande text ökade mest för de elever som fått träna efter QtA. Här kan en orsak vara att såväl elever som lärare läste texten högt vid varje textsamtal. Detta torde gynna elever som har problem med sin avkodning. Eleverna som tränade enligt QtA var initialt långsammare i sin läshastighet (Lundberg, 2010). Den gemensamma läsningen av korta textsegment innebar med stor sannolikhet att eleverna inte i lika hög grad hämmades av sin långsamma, stapplande avkodning. Istället kunde de använda sin energi åt att tillsammans med sina kamrater försöka skapa mening i texten.

Utifrån våra resultat kan vi inte säga att den ena metoden var bättre än den andra. En av orsakerna till detta kan vara att metoderna har likheter med varandra: Båda bygger på direkta, strukturerade samtal ledda av en lärare.

En begränsning i denna studie är att vi till skillnad från Andreassen och Bråten (2011) och Bråten, Anmarkrud, Brandmo och Strømsø (2014) inte kontrollerade för läsmotivation. En annan svaghet är att deltagandet byggde på frivillighet. Denna svaghet måste dock vägas mot styrkan av interventionsmetoden. Interventionsstudier bidrar med unik kunskap därför att de bevisligen utvärderar effekten av olika pedagogiska modeller i läsförståelse.

\section{Litteratur}

Alfassi, M. (1998). Reading for meaning: The efficacy of reciprocal teaching in fostering reading comprehension in high school students in remedial reading classes. American Educational Research Journal, 35(2), 309-332.

Alfassi, M., Weiss, I., \& Lifshitz, H. (2009). The efficacy of reciprocal teaching in fostering the reading literacy of students with intellectual disabilities. European Journal of Special Needs Education, 24, 291-305.

Andreassen, R (2008). Eksplisitt leseforståelseundervisning I norske femteklasser. Et felteksperiment. . Diss. Stavanger: Univ. Stavanger.

Andreassen, R., \& Bråten, I. (2011). Implementation and effects of explicit reading comprehension instruction in fifth-grade classrooms. Learning and Instruction, 21(4), 520-537. 
Antikainen, A. (2006). In search of the Nordic model in education. Scandinavian Journal of Educational Research, 50(3), 229-243.

Asklund, H. (2008). Från vildmark till grön ängel: receptionsanalyser av läsning i åttonde klass. Diss. Uppsala : Uppsala universitet, 2008. Göteborg.

Bandura, A. (1986). Social foundations of thought and action. Prentice Hall.: Englewood Cliffs, NJ.

Beck, I.L. \& McKeown, M.G. (2006). Improving comprehension with questioning the author: a fresh and expanded view of a powerful approach. New York, N.Y.: Scholastic.

Bråten, I., Anmarkrud, Ø., Brandmo, C., \& Strømsø, H. I. (2014). Developing and testing a model of direct and indirect relationships between individual differences, processing, and multiple-text comprehension. Learning and Instruction, 30, 9-24.

Campbell, D.T. and Stanley, J.C. (1963, 1966). Experimental and Quasi-Experimental Designs for Research. Rand McNally, Chicago, Illinois.

Carlgren, I., Klette, K., Mýrdal, S., Schnack, K., \& Simola, H. (2006). Changes in Nordic Teaching Practices: From individualised teaching to the teaching of individuals. Scandinavian Journal of Educational Research, 50(3), 301-326.

Cook, T.D. and Campbell, D.T. (1979). Quasi-Experimentation: Design and Analysis for Field Settings. Chicago: Rand McNally, Chicago, Illinois.

Ewald, A. (2007). Läskulturer: lärare, elever och litteraturläsning i grundskolans mellanår. Diss. Lund: Lunds universitet, 2007. Malmö.

Ferguson, L. E., Bråten, I., Strømsø, H. I., \& Anmarkrud, Ø. (2013). Epistemic beliefs and comprehension in the context of reading multiple documents: Examining the role of conflict. International Journal of Educational Research, 62, 100-114.

Franzén, L. 2002. Läsförståelse. Att göra inferenser - teori och träningsprogram. Solna, Sweden: Ekelund

Goldenberg, C. (1992). Instructional conversations: Promoting comprehension through discussion. The Reading Teacher, 46, 316-326.

Guthrie, J. T., Meter, P., McCann, A. D., Wigfield, A., Bennett, L., Poundstone, C. C., \& Mitchell, A. M. (1996). Growth of literacy engagement: Changes in motivations and strategies during concept-oriented reading instruction. Reading Research Quarterly, 31(3), 306-332.

Hacker, D. J., \& Tenent, A. (2002). Implementing reciprocal teaching in the classroom: Overcoming obstacles and making modifications. Journal of Educational Psychology, 94(4), 699-718.

Jacobson, C. (1995). Översikt över projektet Läsutveckling i Kronoberg. I: Jacobson, C., \& Lundberg, I (Red.), Läsutveckling och dyslexi. Frågor, erfarenheter och resultat (s. 41-51). Stockholm: Liber utbildning.

Jacobsson, C. (2001). Läskedjor. Stockholm: Psykologiförlaget.

Kintsch, W. (1998). Comprehension: A paradigm for cognition. Cambridge university press.

Klingner, J. K., \& Vaughn, S. (1996). Reciprocal teaching of reading comprehension strategies for students with learning disabilities who use English as a second language. The Elementary School Journal, 96(3), 275-293.

Knutas, E. (2008). Mellan retorik och praktik: en ämnesdidaktisk och läroplansteoretisk studie av svenskämnena och fyra gymnasielärares svenskundervisning efter gymnasiereformen 1994. Diss. Umeå: Umeå universitet, 2008. Falun.

Kucan, L., \& Beck, I. L. (1997). Thinking aloud and reading comprehension research: Inquiry, instruction, and social interaction. Review of Educational Research, 67(3), 271-299.

Lederer, J. M. (2000). Reciprocal teaching of social studies in inclusive elementary classrooms. Journal of Learning Disabilities, 33(1), 91-106. 
Lundberg, I. (2001). Vilken bild är rätt? Stockholm: Natur och kultur

Lundberg, I. (2010). Läsningens psykologi och pedagogik. Stockholm: Natur \& kultur

Lundberg, I., \& Reichenberg, M. (2009). Vad är lättläst? Härnösand: Specialpedagogiska skolmyndigheten.

Lundberg, I., \& Reichenberg, M. (2013). Developing reading comprehension among students with mild intellectual disabilities: An intervention study. Scandinavian Journal of Educational Research, 57(1), 89-100.

Madison, S. (1998). Normalisering. Madisons test. Lund: Madisons undervisningskonsult.

Malmqvist, E., \& Forsberg, B. (1984). Vad var det jag läste 2. Lund:LiberLäromedel.

Massey, D. D. (2009). Self-regulated comprehension. Handbook of research on reading comprehension, 389-399.

McIntyre, E., Kyle, D. W., \& Moore, G. H. (2006). A primary-grade teacher's guidance toward small-group dialogue. Reading Research Quarterly, 41(1), 36-66.

McKeown, M. G., Beck, I. L., \&. Blake, R. G. K. (2009a,). Reading comprehension: Focus on content or strategies? Perspectives (International Dyslexia Association), 35(2), 28-32

McKeown, M. G., Beck, I. L., \& Blake, R. G. (2009b). Rethinking reading comprehension instruction: A comparison of instruction for strategies and content approaches. Reading Research Quarterly, 44(3), 218-253.

National Reading Panel, (2000). Report of the National Reading Panel. Washington, DC:

Palincsar, A M. S., \& Brown, A. L. (1984). Reciprocal Teaching of comprehension fostering and comprehension - monitoring activities. Cognition and Instruction. 1, 117175.

Pappas, C.C. (1991). Fostering full access to literacy by including information books. Language Arts, 68(6), 449-462.

Pressley, M., El-Dinary, P. B., Gaskins, I., Schuder, T., Bergman, J. L., Almaso, J., \& Brown, R. (1992). Beyond direct explanation: Instruction of reading comprehension strategies. The Elementary School Journal, 92(5), 513-555.

Pressley, M., Wharton-McDonald, R., Raphael, L. M., Bogner, K., \& Roehrig, A. (2002). Exemplary first grade teaching. Barbara Taylor \& David Pearson (Eds.), Teaching reading: Effective schools, accomplished teachers, 73-88. Mahweh, N J.: Lawrence Erlbaum Associates, inc.

Raphael, T. (1982). Improving question-answering performance through instruction.

(Reading Education Rep. No. 32). Urbana: University of Illinois, Center for the study of reading.

Reichenberg, M. (2000). Röst och kausalitet i lärobokstexter: en studie av elevers förståelse av olika textversioner. Diss. Göteborg: Univ. Göteborg.

Reichenberg, M. (2008). "But before you said you believed that...” A longitudinal study of text talks in small groups. The Reading Matrix, 8(1), 158-185

Rosenshine, B., \& Meister, C. (1994). Reciprocal Teaching: A Review of the Research. Review of Educational Research, 64, 479-530.

Saunders, W. M., \& Goldenberg, C. (1999). Effects of instructional conversations and literature logs on limited-and fluent-English-proficient students' story comprehension and thematic understanding. The Elementary School Journal, 99 (4), 277-301.

Skolverket (2013). PISA 2012. 15 åringars kunskaper i matematik, läsförståelse och naturvetenskap. Rapport nr 398. Stockholm: Fritzes kundservice.

Spörer, N., Brunstein, J. C., \& Kieschke, U. L. F. (2009). Improving students' reading comprehension skills: Effects of strategy instruction and reciprocal teaching. Learning and Instruction, 19(3), 272-286

Söderblom, H. (1990). Sagor att läsa och berätta. Stockholm: En bok för alla. 
Takala, M. (2006). The effects of reciprocal teaching on reading comprehension in mainstream and special (SLI) education. Scandinavian Journal of Educational Research, 50(5), 559-576.

van den Bos, K.P., Nakken, H., Nicholay, P.G., \& van Houten, E.J. (2007). Adults with mild intellectual disabilities: Can their reading comprehension ability be improved? Journal of Intellectual Disability Research, 51, 835-849.

Vygotskij, L.S. (1978). Mind in society: the development of higher psychological processes. Cambridge, Mass.: Harvard U.P.

Westlund, B. (2009). Att undervisa i läsförståelse: lässtrategier och studieteknik. Stockholm: Natur och Kultur.

Wood, D., Bruner, J. S., \& Ross, G. (1976). The role of tutoring in problem solving*. Journal of Child Psychology and Psychiatry, 17(2), 89-100. 